\title{
Analisis Teknik Digital Marketing pada Aplikasi Tiktok (Studi Kasus Akun TikTok @jogjafoodhunterofficial)
}

\section{Analysis of Digital Marketing Techniques in Tiktok Aplication (Case Study of @jogjafoodhunterofficial)}

\author{
Ilham Hilal Ramadhan ${ }^{1}$, Ryan Priatama ${ }^{2 *}$, Az-Zuhaida ${ }^{3}$, Awanis Akalili' ${ }^{4}$, Febriansyah Kulau ${ }^{5 *}$ \\ Jurusan Ilmu Komunikasi, Fakultas Ilmu Sosial, Universitas Negeri Yoguakarta \\ 1ilhamhilal.2019@student.uny.ac.id; 2ryanpriatama.2020@student.uny.ac.id; 3azzuhaida.2020@student.uny.ac.id; \\ 4awanisakalili@uny.ac.id; 5febriansyahkulau.2017@student.uny.ac.id \\ *Penulis koresponden
}

\begin{abstract}
Abstrak
Aplikasi Tiktok di Indonesia banyak dimanfaatkan untuk berkreativitas hingga berbisnis oleh masyarakat. Salah satu akun Tiktok yang aktif dalam menggunakan aplikasi ini sebagai digital marketing adalah @jogjafoodhunterofficial. Akun tersebut merupakan salah satu akun yang berisi mengenai informasi seputar tempat nongkrong dan cafe yang ada di Yogyakarta dengan jumlah pengikut terbanyak. Digital marketing merupakan penerapan teknologi digital untuk menciptkan saluran yang dapat berhubungan dengan konsumen potensial agar tujuan pelaku usaha dapat berjalan secara efektif. Tujuan penelitian ini adalah untuk mengetahui teknik digital marketingyang digunakan oleh akun Tiktok @jogjafoodhunterofficial. Metode penelitian yang digunakan adalah kualitatif dengan menggunakan teknik analisis konten. Hasil penelitian yang didapatkan adalah akun Tiktok @jogjafoodhunterofficial menggunakan teknik digital marketing, yaitu teknik sales promotion. Manfaat penelitian ini adalah untuk menambah wawasan dan penegatahuan serta memberi informasi dan alternatif digital marketing melalui aplikasi Tiktok.
\end{abstract}

Kata Kunci: Tiktok, pemasaran digital, teknik pemasaran digital

\begin{abstract}
The Tiktok application in Indonesia which is widely used for creativity and business by the community. One of the Tiktok accounts that is active in using this application as digital marketing is @jogjafoodhunterofficial. This account is one of the accounts that contains information about hangouts and cafes in Yogyakarta with the largest number of followers. Digital marketing is the application of digital technology to create channels that can connect with potential consumers so that businesses can run effectively. The purpose of this research is to determine the digital marketing techniques that used by @jogjafoodhunterofficial. The research method used is qualitative by using content analysis techniques. The results of the research showed that @jogjafoodhunterofficial account used several digital marketing techniques, which is sales promotion techniques. The benefit of this research is to add insight and knowledge also provide information and digital marketing alternatives through the Tiktok application.
\end{abstract}

Keywords: Tiktok, digital marketing, digital marketing techniques

\section{Pendahuluan}

Tiktok menjadi salah satu media digital marketing yang digunakan oleh para pengguna pelaku bisnis. Menurut Bulele, Y. N. (2020), media Tiktok hadir di Indonesia banyak dimanfaatkan oleh masyarakat untuk berkreatifitas hingga berbisnis. Aplikasi Tiktok pada saat ini memang sering digunakan sebagai pemasaran digital. Misalnya, seperti promosi sebuah produk tebaru, produk make up, promosi tempat nongkrong atau cafe dan yang lainnya. 
Adanya perkembangan teknologi ini telah menghadirkan berbagai media yang bisa digunakan oleh manusia untuk digunakan sebagai alat berkomunikasi. Internet menjadi salah satu dari adanya kemajuan ini, dimana internet pada saat ini telah menjadi kebutuhan seluruh masyarakat. Bisa dilihat mulai dari anak-anak, remaja, sampai orang tua sudah menjadi pengguna internet. Internet memang sudah menjadi kebutuhan yang sangat penting, maka tidak heran jika pengguna internet pada saat ini sangat banyak. Perkembangan internet ini telah menghadirkan interaksi baru bagi masyarakat luas. (Akbar, A., 2006) mengatahkan bahwa, internet menjadi sumber informasi, sebagai sebuah alat komunikasi, dan sebagai alat hiburan. Masyarakat bisa dengan mudah berinteraksi dengan siapa saja dimana saja dan kapan saja.

Internet telah memasuki dalam dunia bisnis yang kemudian telah membuat pergesaran baru salah satunya dalam hal strategi pemasaran. Seseorang sekarang bisa membuat strategi pemasaran terbaru dengan sebuah digital konten dalam mempromosikan produknya ke para konsumen dengan menyebarkan di media sosial. Mengingat bahwa sekarang pengguna media sosial itu sangat banyak. Kemunculan internet ini memang membawa pengaruh yang cukup besar dalam dunia bisnis khususnya dalam pemasaran yang dilakuakan di media sosial. Pemasran secara online inilah yang kemudian disebut dengan digital marketing (pemasaran digital). Digital marketing (pemasaran digital) merupakan penggunaan teknologi guna membantu aktivitas pemasaran yang memiliki tujuan untuk memberikan informasi kepada konsumen dengan cara menyesuaikan kebutuhan mereka (Caffey, 2013). Memang saat ini sudah banyak para pebisnis yang melakukan digital marketing untuk memasarkan dan mempromosikan produknya itu.

Tujuan dari digital marketing atau pemasaran digital ini sendiri yaitu untuk menghubungkan konsumen dan juga perusahaan yang mana dapat berbagi informasi serta berkomunikasi (Coviello, $\mathrm{N}$. Milley, R. \& Marcolin, B., 2001). Kegiatan digital marketing ini memang sudah menjadi tren tersendiri di zaman sekarang ini.
Terdapat beberapa platform media sosial yang bisa digunakan seperti, Instagram, Twitter, situs web, Tiktok, dan lain-lain. Media sosial dapat digunakan selain untuk berkelana di dunia maya, juga sekarang digunakan untuk mempromosikan suatu produk tertentu. Saat ini aplikasi Tiktok menjadi salah satu platform media sosial yang banyak digunakan untuk kegiatan digital marketing ini. Aplikasi Tiktok ini memang menampilkan fitur-fitur yang kekinian yang mana dapat menarik para pengguna Tiktok untuk menggunakannya.

Akun Tiktok dengan nama @jogjafoodhunterofficial ini menjadi salah satu contoh akun Tiktok yang digunakan sebagai pemasaran digital. Akun tersebut berisi mengenai berbagai informasi seputar tempat nongkrong dan cafe yang ada di Yogyakarta. Akun @jogjafoodhunterofficial ini sudah memiliki jumlah followers sekitar 549 ribu dengan viewers sebanyak 13 juta viewers, hal ini dapat dilihat pada Gambar 1. Akun@jogjafoodhunterofficial membuat 410 konten video setiap harinya. Kontenkonten yang ada di dalam akun tersebut juga menarik para pengguna akun Tiktok untuk melihatnya.

Tiktok merupakan salah satu media sosial yang memberikan tempat kepada para penggunanya untuk bisa berekspresi serta berkreatifitas melalui konten video (Abdulhakim, A., 2019). Para pengguna Tiktok ini kebanyakan berasal dari kalangan remaja serta dewasa muda (sekitar 16-24 tahun). Dimana mereka inilah salah satu audien yang bagus untuk pemasaran di Tiktok yang mana pemasaran yang sangat potensial bagi sebuah produk (Rasyid, M. H., 2020). Pemanfaatan platform media Tiktok ini dapat digunakan untuk sebuah digital marketing. Mengingat terdapat fitur-fitur pendukung yang ada di aplikasi Tiktok yang dapat membuat suatu konten bisa lebih menarik. Berdasarkan uraian diatas, maka peneliti akan mengungkapkan permasalahan pada penelitian ini adalah "Bagaimana teknik yang digunakan dalam digital marketing pada aplikasi Tiktok @jogjafoodhunter?”. 

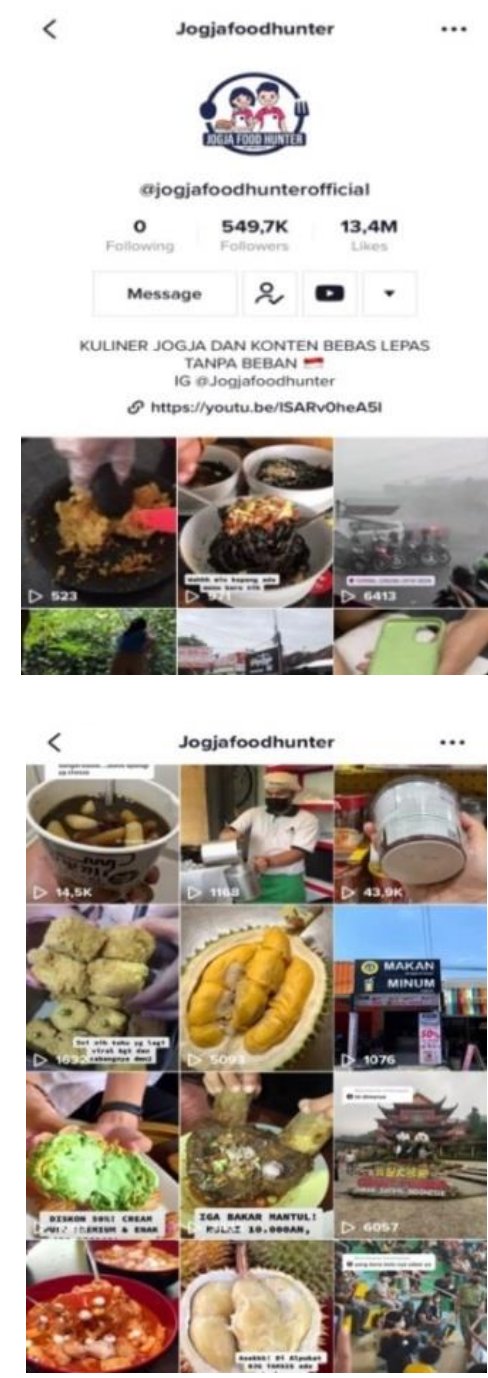

Gambar 1. Akun Tiktok

@jogjafoodhunterofficial

\section{Tiktok Sebagai The Big New Media}

Seiring berjalannya waktu, perkembangan teknologi dan informasi semakin meningkat. Beberapa terobosan yang bersifat baru maupun disempurnakan menjadi pertanda bahwa teknologi kita saat ini berada di level yang telah meningkat. Salah satunya adalah adanya aplikasiaplikasi yang dengan mudah mampu dikelola dan dikonsumsi oleh masyarakat. Aplikasi-aplikasi ini mampu memberikan fasilitas yang dapat menunjang para penggunanya. Contoh aplikasi yang sedang hangat di masyarakat kali ini adalah aplikasi Tiktok.

Aplikasi yang dibuat oleh Zhang Yiming dari China ini diluncurkan secara resmi pada September 2016. Tiktok merupakan sebuah platform atau aplikasi sosial media yang berfokus pada berbagi video pendek antar penggunanya (Su, dkk., 2020). Lebih jelas Su, dkk. (2020) dalam jurnal yang berjudul "Fan
Engagement in 15 Seconds: Athletes' Relationship Marketing During a Pandemic via Tiktok" memaparkan bahwa pengguna bisa memanfaatkan bermacam-macam template, filter, dan efek visual, serta perpustakaan musik bawaan, untuk membuat video pendek. Dalam jurnal ini juga dijelaskan bahwa Tiktok secara bertahap bergerak maju menjadi sebuah platform media sosial yang lebih dikomersialkan dan memungkinkan pengguna memperoleh pendapatan dari pembelian dalam aplikasi dan reaksi atau hadiah berbayar sebagai tanggapan atas video mereka.

Banyak pakar media sosial menyebutkan bahwa Tiktok akan menjadi "The Big New Media". Hal ini didukung oleh jumlah pengunduh aplikasi ini. Dalam laman databoks.katadata.co.id menyebutkan bahwa aplikasi Tiktok mendapatkan total jumlah unduhan sebesar lebih dari 2 miliar per tiga bulan pertama di tahun 2020. Aplikasi ini menambahkan 12 juta pengguna AS pada bulan Maret 2020 dan total 52,2 juta pengguna secara global (Weiss, G., 2020) menjadikan aplikasi ini sebagai aplikasi dengan jumlah unduhan terbanyak untuk kategori non-gaming pada kuartal pertama 2020 (Leskin, P., 2020). Selain itu waktu yang dihabiskan untuk membuka aplikasi Tiktok juga meningkat. Misalnya, pengguna di Amerika Serikat menghabiskan rata-rata 8 jam di aplikasi selama bulan Maret, 10,8\% lebih tinggi dari waktu yang dihabiskan pada bulan Januari (Weiss, G., 2020). Menurut data Sensor Tower, total unduhan terbanyak berada di Indonesia dengan memetakan $11 \%$ total unduhan. Kemudian disusul oleh Brazil dengan total unduhan sebesar 9\%.

Data-data tersebut menunjukan bahwa Tiktok kini menjadi platform atau aplikasi media sosial yang memiliki kekuatan tersendiri untuk menarik perhatian penggunannya. Seiring perkembangannya, aplikasi Tiktok ini digunakan tidak hanya hiburan semata, akan tetapi juga bisa digunakan sebagai digital marketing baru. Penelitian yang dilakukan oleh Dewa dan Safitri (2021) dengan judul "Pemanfaatan Media Sosial Tiktok Sebagai Media Promosi Industri Kuliner Di Yogyakarta Pada Masa Pandemi Covid-19 (Studi Kasus Akun Tiktok Javafoodie)", menunjukan bahwa Tiktok merupakan media yang ideal dalam 
mempromosikan industri kuliner di Daerah Istimewa Yogyakarta. Akun Tiktok Javafoodie menjadi salah satu akun Tiktok di Yogyakarta yang mempromosikan beragam kuliner khas Yogyakarta.

\section{Digital Marketing di Era Disrupsi}

Digital marketing menurut Chaffey (2015) dengan e-marketing memiliki kemiripan arti. Keduanya berkaitan dengan manajemen dan pengaplikasian pemasaran menggunakan media elektronik yakni teknologi digital yang memberikan kontribusi terhadap kegiatan pemasaran yang memiliki maksud mendapat keuntungan serta memebangun dan mengembangkan hubungan antar penjual dan pelanggan. Selain itu juga mendekatkan hubungan dengan pelanggan sehingga meningkatkan pengetahuan mengani konsumen yang selanjutnya menyatukan komunikasi dengan pelayanan online sesuai kebutuhan pelanggan dengan spesifik. Sawicki, A. (2016) mengartikan digital marketing sebagai eksploitasi terhadap teknologi digital untuk menciptakan saluran yang dapat berhubungan dengan resipien potensial agar tujuan perusahaan dalam memenuhi kebutuhan konsumen dapat berjalan efektif. Sehingga, digital marketing secara sederhana dapat dikatakan sebagai tujuan pemasaran yang dilakukan dengan media dan teknologi digital untuk mempermudah pelaku bisnis maupun calon konsumen.

Tujuan dilakukannya digital marketing adalah untuk mempromosikan brand atau merek, mengenalkan preferensi, meningkatkan penjualan dengan berbagai teknik digital marketing. Macam-macam teknik digital marketing diantaranya social media optimization, search engine optimization (SEO), search engine marketing (SEM), content marketing, influencer marketing, content automation, campaign marketing, e-commerce marketing, e-mail direct marketing, display advertising, ebooks, optical disks, games dan bentuk digital marketing lainnya (Saveria, R. A., 2016).

Beberapa penelitian yang sudah dilakukan menunjukan berbagai macam teknik digital marketing, seperti penelitian oleh Indrawati dkk. (2017) dalam jurnal yang berjudul "Efektivitas Iklan Melalui
Media Sosial Facebook Dan Instagram Sebagai Salah Satu Strategi Pemasaran Di Krisna Oleh-Oleh Khas Bali" yang memaparkan bahwa iklan adalah teknik digital marketing yang digunakan oleh Krisna. Selain itu, Penelitian yang dilakukan oleh Puspitarini, D. S., \& Nuraeni, R. (2019) dengan judul "Pemanfaatan Media Sosial Sebagai Media Promosi (Studi Deskriptif pada Happy Go Lucky House)", memaparkan bahwa terdapat beberapa kegiatan promosi yang dilakukan berupa iklan, diskon, giveaway, testimoni konsumen, feed, memberikan informasi mengenai toko pada profil instagram, dan terdapat sesi yang memperlihatkan produk-produk baru.

Teknik-teknik lain juga ditemukan dalam beberapa penelitian, seperti penelitian yang dilakukan oleh Romo, Z. F. G., Medina, I. G., \& Romero, N. P. (2017) dengan judul "Storytelling and Social Networking as Tools for Digital and Mobile Marketing of Luxury Fashion Brands" menunjukan bahwa strategi yang digunakan brand fashion besar dalam digital marketing adalah teknik storytelling. Teknik ini menjadi salah satu kunci strategi dalam digital marketing. Selain itu Hayu, R. S. (2019) dengan judul penelitian "Smart Digital Content Marketing, Strategi Membidik Konsumen Millenial Indonesia" menuliskan beberapa strategi dalam digital marketing yang disebut "Smart Digital Content Marketing" diantaranya, konten optimasi media sosial, endorse, unboxing, tagar, testimoni, promo, tantangan untuk konsumen, dan hubungan dengan konsumen melalui interaksi yang terjadwal dan teragenda.

\section{Metode}

Metode yang akan digunakan dalam penelitian ini adalah kualitatif. Menurut Kirk, J., Miller, M. L., \& Miller, M. L. (1986) metodologi kualitatif merupakan sebuah tradisi tertentu dalam ilmu pengetahuan sosial yang secara fundamental bergantung kepada pengamatan manusia dan berhubungan dengan orang-orang tersebut dalam bahasannya dan dalam peristilahannya. Secara umum pengertian penelitian kualitatif adalah sebuah metode berganda dalam fokus yang melibatkan suatu pendekatan interpretative serta wajib terhadap setiap pokok permasalahnnya. 
Metodologi yang akan dipakai dalam penelitian ini yaitu studi kasus.

Metode pengumpulan data yang akan digunakan yaitu menggunakan teknik analisis konten. Menurut Zuchdi, D. (1993) metode teknik analisis konten ini digunakan untuk menganalisis serta memahami mengenai pesan simbolik dalam bentuk seperti dokumen, artikel, karya sastra, dan lainnya yang termasuk data tidak berstruktur. Penelitian ini menggunakan teknik triangulasi untuk validasi data. Trangulasi merupakan teknik yang digunakan untuk memeriksa keabsahan data yang memanfaatkan sesuatu di luar data untuk mengecek serta sebagai pembanding terhadap data tersebut (Lexy, J. M., 2010). Peneliti menggunakan triangulasi peneliti, dimana melibatkan peneliti yang berbeda disiplin ilmunya dalam suatu penelitian yang sama. Teknik triangulasi peneliti ini juga nantinya diharapkan untuk mendapatkan khasanah pengetahuan terhadap informasi yang dicari dari subjek penelitian.

\section{Hasil dan Pembahasan Iklan}

Tiktok saat ini menjadi salah satu platform media sosial yang digunakan sebagai digital marketing. Melalui tiktok, barang atau produk yang ingin dijual bisa dibagikan melalui beberapa teknik digital marketing. Berdasarkan analisis konten yang telah peneliti lakukan sebanyak 100 konten dalam akun tiktok @jogjafoodhunterofficial ditemukan beberapa teknik digital marketing, yaitu iklan, storytelling, komedi, diskon, testimoni, tagar, tanya jawab, promo, cashback, audio musik, dan feedback.

Iklan merupakan salah satu teknik promosi yang biasanya digunakan untuk mengarahkan komunikasi yang bersifat persuasif pada konsumen sasaran dan bentuk penyajiannya bersifat non-personal (Saladin, D., \& Oesman, Y., 2002). Teknik iklan menjadi salah satu teknik yang digunakan oleh akun tiktok @jogjafoodhunterofficial dalam mengelola konten digital marketingnya, ha ini dapat dilihat pada Gambar 2. Teknik ini juga ditemukan dalam penelitian relevan yang dilakukan oleh Indrawati dkk., (2017) dengan judul "Efektivitas Iklan Melalui Media Sosial Facebook dan Instagram Sebagai Salah Satu Strategi Pemasaran Di
Krisna Oleh-Oleh Khas Ball". Dalam penelitian ini disebutkan bahwa iklan menjadi teknik digital marketing yang dilakukan oleh Krisna oleh-oleh kas Bali. Teknik iklan dalam akun Tiktok @jogjafoodhunterofficial menggunakan kaliamat persuasif dan yang diiklankan merupaka sebuah toko atau warung yang bersifat nonpersonal. Dalam konten yang dianalisis peneliti, menunjukan bahwa teknik iklan disertai dengan penjelasan yang detail dan informatif. Hal ini sesuai dengan pernyataan yang dipaparkan oleh $\mathrm{Ha}$, Y. W., Park, M. C., \& Lee, E. (2014) iklan juga harus bersifat informatif.

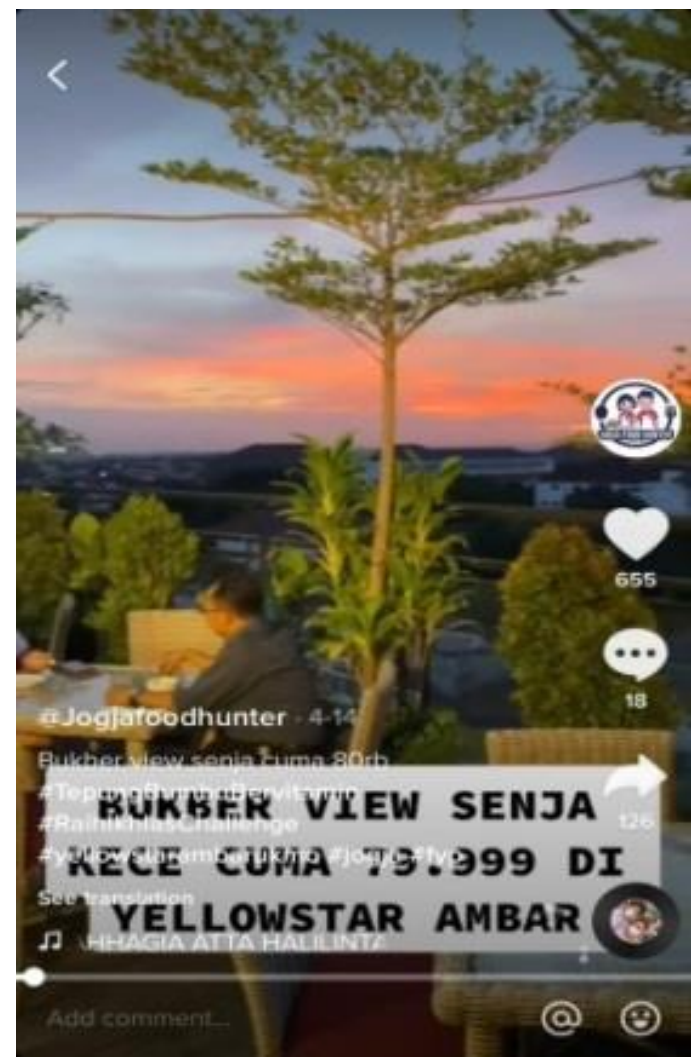

Gambar 2. Teknik Iklan Pada Akun

@jogjafoodhunterofficial 14/04/2021

(https://vt.tiktok.com/ZSJBSDEm1/)

\section{Story Telling}

Teknik selanjutnya yang juga ditemukan dalam akun tiktok @jogjafoodhunterofficial adalah story telling atau bercerita. Hal ini dapat dilihat pada Gambar 3 dengan adanya tulisan "Baru lagi di Jogja! Makan steamboat view sawah, kece banget." Teknik ini sering digunakan sebagi teknik digital marketing oleh akun tiktok @jogjafoodhunterofficial. Dalam penggunaan tekniknya, @jogjafoodhunterofficial bercerita mengenai tempat yang ada di dalam konten videonya. 
Ceritanya beragam, mulai dari cerita perjalanan menuju ke tempat lokasi, cerita tentang kondisi dan suasan lokasi, cerita tentang produk atau barang yang dijual di lokasi, dan lain-lain. Teknik ini juga selaras dengan penelitian dengan judul "Pemanfaatan Media Sosial Tiktok Sebagai Media Promosi Industri Kuliner Di Yogyakarta Pada Masa Pandemi Covid-19 (Studi Kasus Akun Tiktok Javafoodie)" oleh Dewa, C. B., \& Safitri, L. A. (2021). Dalam penelitian ini dijelaskan bahwa akun Tiktok @Javafoodie menggunakan narasi cerita dalam menyampaikan infomasi kepada para pengikutnya.

Teknik story telling juga ditemukan pada digital marketing yang dilakukan oleh brand fashion besar dunia, seperti Prada, Chanel, dan Louis Vuitton. Temuan ini dituliskan dalam penelitian yang dilakukan oleh Romo, Z. F. G., Medina, I. G., \& Romero, N. P. (2017) dengan judul "Storytelling and Social Networking as Tools for Digital and Mobile Marketing of Luxury Fashion Brands". Hal ini menunjukan bahwa story telling menjadi salah satu teknik digital marketing yang sering digunakan dalam media sosial.

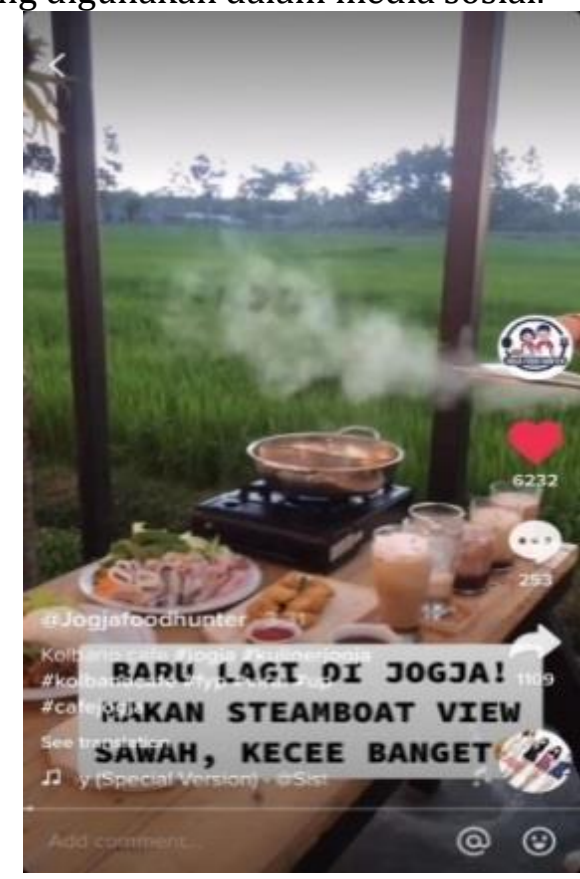

Gambar 3. Teknik Story Telling Pada Akun @jogjafoodhunterofficial 31/03/2021 (https://vt.tiktok.com/ZSJBSJTLo/)

\section{Komedi}

Pada penelitian ini, peneliti juga menemukan adanya teknik komedi yang digunakan dalam konten Tiktok akun @jogjafoodhunterofficial. Teknik komedi yang dilakukan oleh akun ini berada pada audio yang digunakan, narasi yang diucapkan, dan caption yang dituliskan.

Dalam konten tersebut, teknik komedi ditunjukan melalui caption yang ditulis oleh akun tiktok @jogjafoodhunterofficial. Pada Gambar 4 terdapat caption yang bertuliskan "gak mobil aja yang pajero ternyata bakso juga pajero", kalimat humoris ini menjadi salah satu hal yang menandakan bahwa konten ini menggunakan teknik komedi disamping juga mengombinasikan dengan teknik digital marketing yang lain. Penemuan teknik komedi dalam digital marketing juga ditemukan dalam penelitian yang dilakukan oleh Dewa, C. B., \& Safitri, L. A. (2021) dengan judul "Pemanfaatan Media Sosial Tiktok Sebagai Media Promosi Industri Kuliner Di Yogyakarta Pada Masa Pandemi Covid-19 (Studi Kasus Akun Tiktok Javafoodie)". Dalam akun tiktok @Javafoodie secara konsisten menggunakan teknik komedi dalam digital marketing. Akun ini ingin menampilkan karakter komedi yang ceria dan menghibur dalam setiap konten yang diunggahnya. Oleh karena itu, videovideo yang diunggah secara konsisten menggunakan teknik komedi sehingga karakter komedi pun terbentuk. Walaupun sama-sama ditemukan teknik komedi, penelitian yang dilakukan dalam akun tiktok @jogjafoodhunterofficial tidak menunjukan teknik komedi sebagai karakter utama yang ingin dibentuk oleh akun ini. Hal ini ditunjukan kurang konsistennya akun ini dalam menggunakan teknik komedi pada konten-kontennya. Akun @jogjafoodhunterofficial hanya menggunakan teknin ini sebagai selingan dan memperkaya jenis konten yang dihasilkan.

\section{Tagar, Feedback, Audio Musik}

Mulanya, hashtag atau tagar menjadi salah satu fitur media sosial dalam mengelompokkan konten tertentu (Oktavia, 2019). Tagar dapat memengaruhi peran serta konsumen yang lebih tinggi lebih dari $50 \%$ pertumbuhan perpostingan. Tagar telah banyak dilakukan oleh pemasar sebagai alat komunikasi pemasaran atau promosi (Stathopoulou, A., Borel, L., Christodoulides, G., \& West, D., 2017). Sehingga, tagar dapat mempermudah 
pencarian produk yang didambakan oleh konsumen (Dewa, C. B., \& Safitri, L. A., 2021).

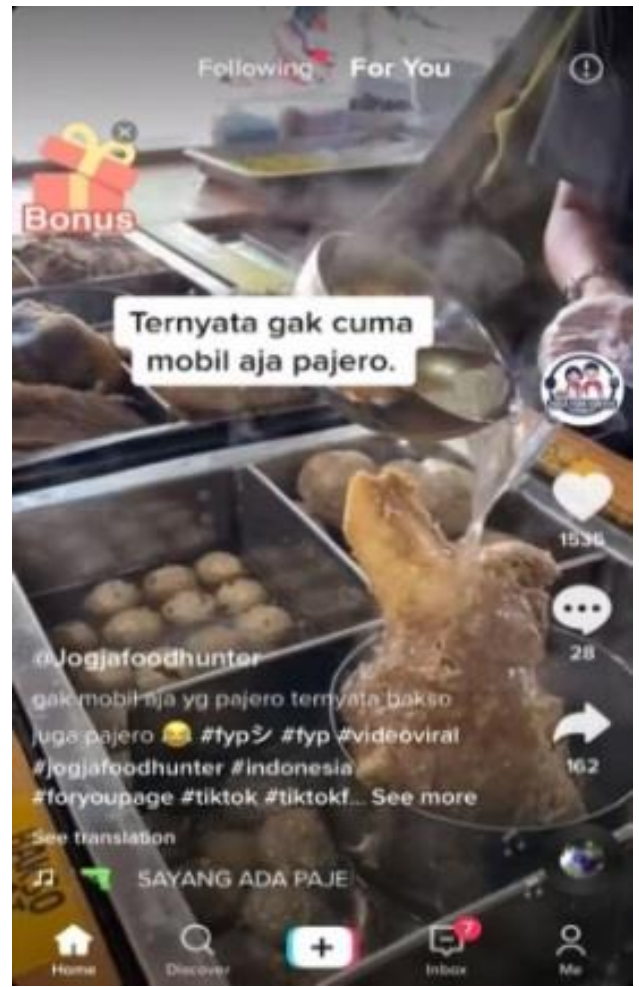

Gambar 4. Teknik Komedi Pada Akun @jogjafoodhunterofficial 28/02/2021 (https://vt.tiktok.com/ZSJhft8je/)

Keefektifan tagar membuat pelaku usaha menggunakan tagar dalam mempromosikan produknya. Setelah dianalsis lebih lanjut, konsep digital marketing menggunkan tagar telah dilakukan oleh akun @jogjafoodhunterofficial. Dari 100 video terpilih peneliti, seluruh video menggunakan tagar untuk meningkatkan engagement pengguna akun Tiktok lainnya.

Pada Gambar 5, bisa dilihat bahwa menggunakan tagar pada akun Tiktok @jogjafoodhunterofficial. Dalam video tersebut, menyebutkan tagar \#fyp \#videoviral \#fyp \#KibasSampaiLusa \#jogjafoodhunter \#indonesia \#tiktokfoodie \#viral \#jogja \#tiktok dan \#kuliner. Penggunaan tagar bermaksud untuk meningkatkan engagement (Stathopoulou, A., Borel, L., Christodoulides, G., \& West, D., 2017). Dibuktikan dari video tersebut pada konten digital marketing diatas sejauh ini mendapatkan jumlah viewers sebanyak 4,5 juta sejak terupload pada 23 Januari 2021.

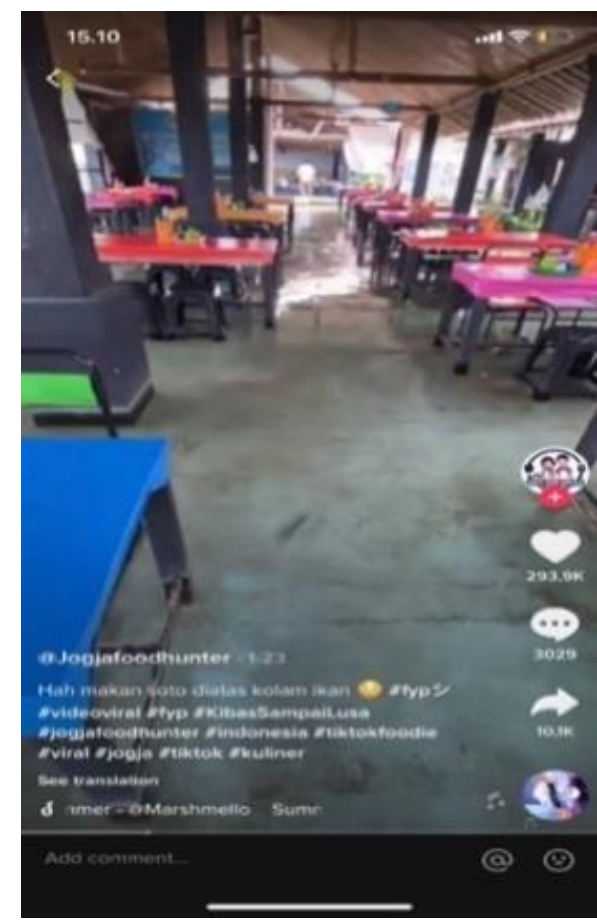

Gambar 5. Penggunaan tagar Pada Akun

@jogjafoodhunterofficial 23/01/2021

(https://vt.Tiktok.com/ZSJrV591M/)

Tagar sendiri telah digunakan oleh seluruh video terpilih peneliti dalam akun @jogjafoodhunterpfficial. Setiap video menggunakan tagar adalah \#fyp \#fyp シ \#foryourpage \#jogjafoodhunter \#Tiktokfoodie \#kulinerjogja \#jogja dan sebagainya. Makna tagar \#fyp \#fyp シ \#foryourpage digunakan untuk video yang diunggah dapat ditonton atau masuk dalam halaman utama pengguna akun Tiktok yang walaupun tidak mengikuti akun @jogjafoodhunterofficial. Hal ini diharapkan dapat menarik perhatian pengguna akun Tiktok lainnnya untuk mengikuti atau follow akun@jogjafoodhunterofficial. Tagar \#jogjafoodhunter juga dicantumkan dalam unggahan video @jogjafoodhunter. Dari 100 video yang dipilih peneliti terdapat 45 video yang menggunakan tagar \#jogjafoodhunter. Hal ini membuat ciri khas dari setiap unggahan video dari akun Tiktok @jogjafoodhunter. Penggunaan tagar \#jogjafoodhunter sejauh ini sudah ditonton sebanyak 132,1 juta kali. Penggunaan tagar \#Tiktokfoodie \#kulinerjogja \#jogja juga digunakan oleh akun @jogjafoodhunterofficial. Tagar tersebut dapat mempermudah pengguna akun Tiktok yang ingin mencari video yang terkait dengan tagar tersebut. 
Salah satu keuntungan menggunakan media sosial Tiktok adalah dapat dengan mudah membangun relationship secara interaktif dan mendapatkan feedback antar sesama pengguna (Dewa, C. B., \& Safitri, L. A., 2021). Akun @jogjafoodhunterofficial menggunakan feedback sebagai salah satu strategi dalam digital marketing. Dalam 100 video terpilih terdapat 5 video yang menggunakan strategi feedback atau umpan langsung dari pengguna akun Tiktok lain. Feedback dari Tiktok didapatkan dari komentar pengguna akun lain di video yang kemudian dijawab langsung dengan membuat video lain. Salah satu contohnya ditunjukkan di Gambar 6.

Terdapat interaksi feedback pada akun @abdultasman "ga tau min, makannya kasih tau donk, biar bsok bisa mampir (-)". Akun @jogjafoodhunter menjawab komentar dengan bentuk video. Dalam video tersebut, akun@jogjafoodhunter@menjawab pertanyaan@abdultasman yang bertanya mengenai tempat yang dibuat dalam video sebelumnya agar dijelaskan lebih rinci. Pengguna @abdultasman juga menyebutkan bahwa terdapat iktikad untuk datang ke tempat yang terdapat dalam video. Dari komentar tersebut, dapat diambil kesimpulan bahwa perilaku digital marketing yang dilakukan akun @jogjafoodhunter cukup berhasil. Selain promosi, penggunaan fitur feedback juga membentuk komunikasi secara interaktif oleh pengguna lainnya. Pengguna lain seperti@abdultasman dapat memberikan komentarnya yang kemudian dapat dijawab oleh pembuat konten sehingga dapat membangun relationship antar-pengguna.

Dalam penelitian ini, penelitian menemukan temuan terbaru pada konten digital marketing di akun @jogjafoodhunterofficial. Pada konten tersebut terdapat penambahan penggunaan audio musik. Jadi dalam konten tersebut tidak hanya menampilkan video saja, tetapi juga terdapat audio musik. Penggunaan audio musik pada konten digital marketing di akun @jogjafoodhunterofficial sangat sering digunakan. Pasalanya bisa dilihat dalam akun Tiktok @jogjafoodhunterofficial hampir semua konten yang ada di akun Tiktok tersebut menggunakan audio musik dalam konsep digtal marketingnya.

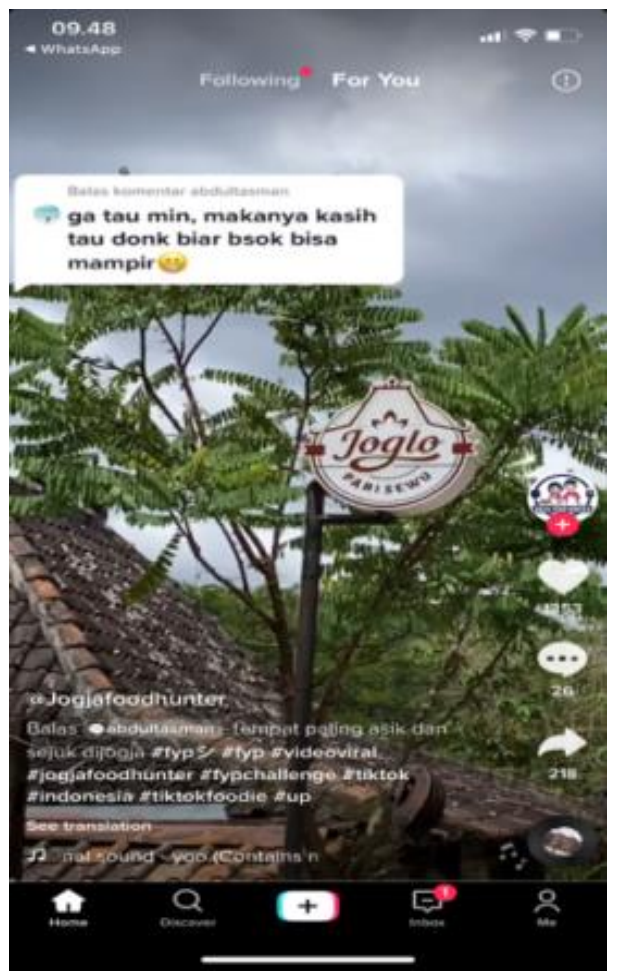

Gambar 6. Teknik Feedback Pada Akun @jogjafoodhunterofficial 14/02/2021 (https://vt.Tiktok.com/ZSJrq1vYD/)

Pada Gambar 7, dapat terlihat ada simbol musik berserta dengan judul lagu dan penyanyinya. Berdasarkan analisis konten yang sudah dilakukan, penggunakan audio musik dalam konten digital marketing ini dimaksudkan untuk menarik perhatian para pengguna Tiktok. Audio musik yang digunakan misalnya lagu Put Your Had On My Shoulder, Dance Monkey, Classic Music, Sesuatu di Jogja, Ampun Bang Jago dan masih banyak yang lainnya. Hal ini dinilai dapat menarik perhatian pengguna Tiktok, dibuktikan dengan jumlah viewers pada konten Gambar 7 yang tembus hingga 4,2 juta viewers pada tanggal 14 April 2021.

\section{Sales promotion digital marketing}

Kegiatan sales promotion kerap digunakan oleh para pelaku bisnis. Sales promotion merupakan kumpulan kiat intensif yang beragam, biasanya berjangka pendek, yang berguna untuk mendorong pembelian produk/jasa tertentu secara cepat (Kotler, P., \& Keller, K. L., 2012). Dalam menjalankan sebuah bisnis dengan konsep digital marketing tentu sales promotion menjadi hal yang penting. Sales promotion ini bisa berupa diskon, cashback, promosi, testimoni dan lainnya. Sales promotion berupa promosi, diskon, 
testimoni dan cashback ini juga ditemukan dalam digital marketing pada konten akun Tiktok

@jogjafoodhunterofficial. Berdasarkan analisis konten pada akun Tiktok@jogjafoodhunter, penerapan sales promotion dalam digital marketing cukup menarik perhatian para pengguna akun Tiktok.

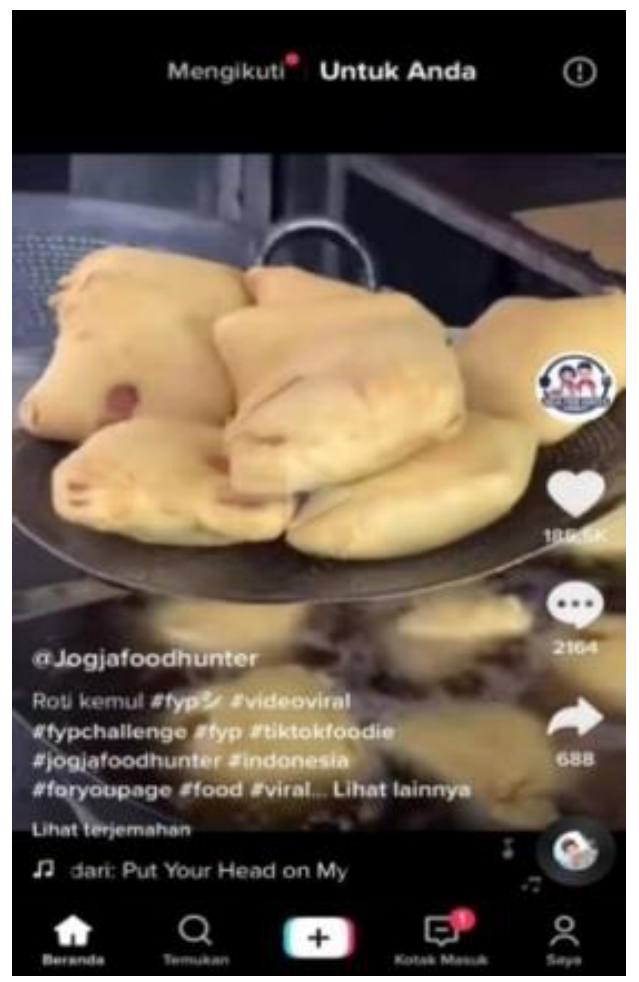

Gambar 7. Penggunaan audio musik pada akun@jogjafoodhunterofficial 27/10/2020

(https://vt.tiktok.com/ZSJBSJS2F/ )

Pada penelitian yang dilakukan Setyaningrum, N., Waluyo, H. D., \& Wijayanto, A. (2014), menyebutkan bahwa penarapan sales promotion seperti promosi dan testimoni ini digunakan sebagai startegi smart digital content marketing yang dianggap sudah mengakomodasi karakteristik konsumen milenial Indonesia. Dalam penelitian ini, ditemukan bahwa konsep digital marketing pada akun Tiktok @jogjafoodhunter juga menggunakan sales promotion sebagai salah satu strateginya. Oleh karena itu, berdasarkan data tersebut dapat kita lihat bahwa, penggunaan sales promotion menjadi salah satu strategi atau teknik yang bisa diterapkan dalam digital marketing.

Lain halnya dengan penelitian yang dilakukan oleh Puspitarini, D. S., \& Nuraeni, R. (2019) yang menemukan bahwa, teknik promosi di media sosial digunakan untuk memperkenalkan dan membangun citra pelaku bisnis di akun Instagram. Setelah dianalisis lebih lanjut, konsep digital marketing dengan teknik sales promotion kerap dilakukan pada akun Tiktok @jogjafoodhunteroffcial. Hal tersebut dinilai tepat sebagai sebuah teknik atau strategi dalam digital marketing. Hal ini pula juga disampaikan oleh Tabroni, T., \& Komarudin, M. (2021), dalam penelitiannya menyebutkan, teknik promosi dalam digital marketing dapat dibilang tepat dan sering dilakukan oleh para pelaku usaha serta berpengaruh signifikan terhadap kepuasan audien.

Pada Gambar 8, bisa dilihat bahwa terdapat teknik sales promotion berupa promo dalam konten digital marketing pada akun Tiktok @jogjafoodhunter. Menurut Tjiptono, F. (2008) promosi adalah elemen bauran pemasaran yang mana bertujuan sebagai upaya memberikan informasi, membujuk, serta mengingatkan kembali kepada konsumen akan merek dan poduk suatu perusahaan. Konsep sales promotion pada konten tersebut juga dinarasikan oleh informan "Haaa.. Promo ikan bakar hanya 9.900 per ekor". Penggunakan teknik sales promotion tersebut bertujuan untuk menarik para pengguna Tiktok. Hal tersebut bisa dibuktikan pada konten digital marketing di atas, jumlah viewers mencapai hingga 248,5 ribu pada tanggal 14 April 2021.

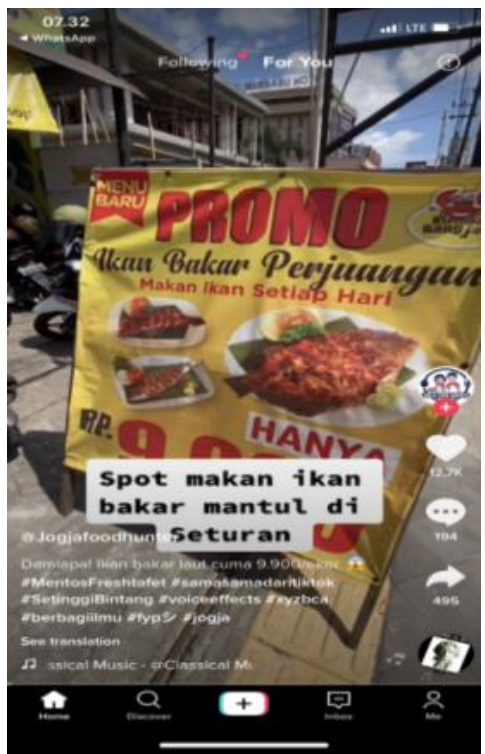

Gambar 8. Penggunaan teknik promosi pada konten@jogjafoodhunterofficial $25 / 09 / 2020$

(https://vt.Tiktok.com/ZSJrVn9Ej/) 


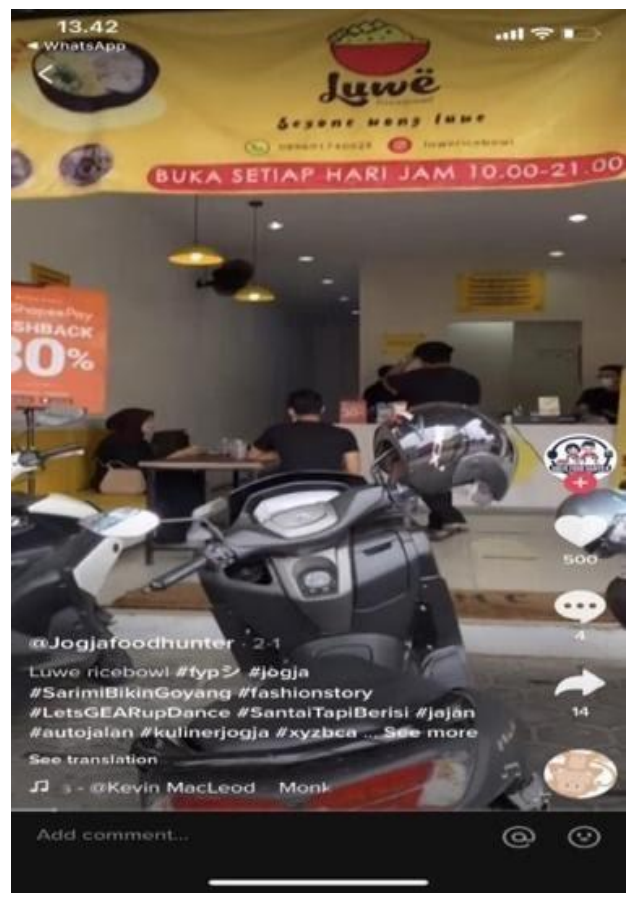

Gambar 9. Penggunaan teknik diskon pada konten@jogjafoodhunterofficial $01 / 02 / 2021$

(https://vt.Tiktok.com/ZSJrqeW4r/)

Gambar 9 menunjukkan teknik sales promotion berupa diskon atau potongan harga. Diskon merupakan pengurangan langsung dari harga barang pada pembelian pada suatu periode tertentu yang sudah ditentukan (Kotler, P., \& Amstrong, G., 2004). Gambar 9 berasal dari salah satu konten digital marketing yang ada di akun Tiktok@jogjafoodhunterofficial. Konten tersebut berupa video dengan ada satu informan yang bebicara. Dalam konten tersebut informan mengatakan "nah lagi ada promo opening mantul nih gaes, beli 1 gratis 1 dan diskon $20 \%$ all menu, sampai tanggal 2 februari". Menerapkan sales promotion berupa diskon dalam digital marketing memang menjadi daya tarik sendiri bagi para pengguna untuk melihatnya. Hal tersebut terlihat dalam jumlah viewers yang mencapai hingga 20,4 ribu pada tanggal 14 April 2021.

Gambar 10 merupakan salah satu konten digital marketing yang ada di akun Tiktok @jogjafoodhunterofficial. Peneliti menemukan temuan terbaru pada konten tersebut. Konten itu menggunakan teknik sales promotion berupa cashback. Cashback ini sendiri merupakan sebuah strategi pemasaran berupa penawaran presentase uang pengembalian. Dalam konten tersebut dikatakan bahwa ada promo berupa cashback "nah lagi banyak promo nih di bakso abang kita, ada promo 25 ribu, ada cashback 45 ribu dan ada diskon ongkir juga". Seperti yang sudah dibahas di atas, bahwa penggunaan teknik sales promotion ini kerap digunakan dalam digital marketing.

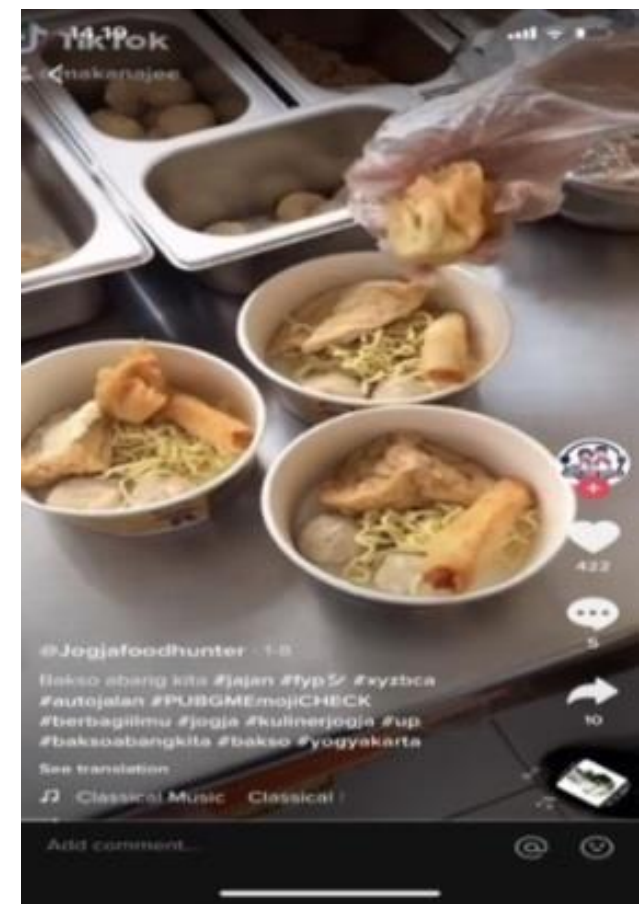

Gambar 10. Penggunaan teknik cashback pada konten @jogjafoodhunterofficial $8 / 01 / 2021$

(https://vt.Tiktok.com/ZSJrq1KTx/)

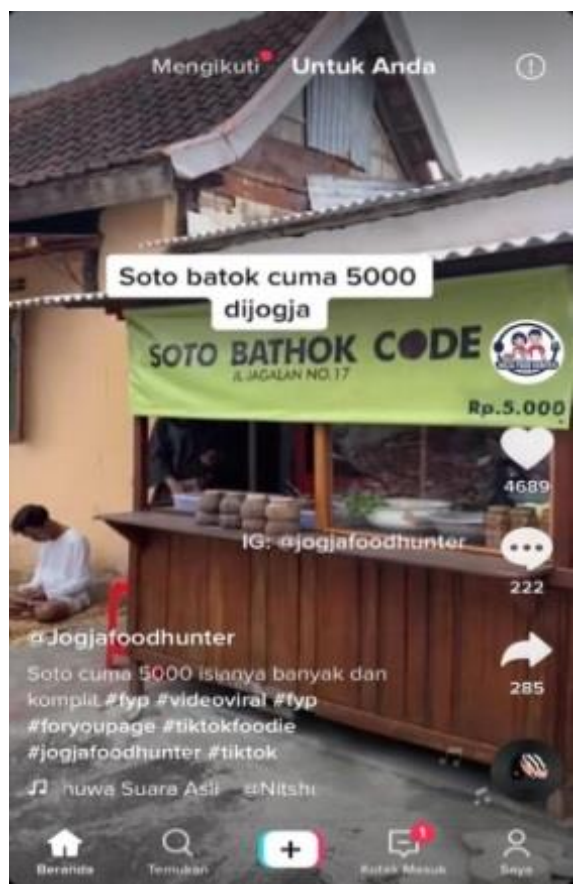

Gambar 11. Penggunaan teknik testimoni pada konten @jogjafoodhunterofficial $20 / 03 / 2021$

(https://vt.Tiktok.com/ZSJrVGdPe/) 
Gambar 11 menunjukkan konten digital marketing yang menggunakan teknik sales promotion. Teknik sales promotion yang digunakan yaitu testimoni. Testimoni yaitu salah satu kegiatan promosi pemasaran berupa bentuk kesaksian yang dilakukan oleh konsumen yang telah merasa puas atau kurang puas atas produk atau jasa yang sudah pernah dibeli. Konten tersebut berupa video dengan durasi 1 menit. Dalam video konten tersebut memberikan sebuah testimoni terhadap soto batok yang ada di jogja. Testimoni tersebut berupa suara dan teks dalam video "Soto batok cuma 5000. Isinya komplit dan dagingnya gak pelit gaesss. Tempatnya asik pinggir Kali Code".

\section{Kesimpulan}

Akun@jogjafoodhunterofficial menggunakan beberapa teknik digital marketing. Dari penelitian ini, peneliti menemukan teknik digital marketing yang dilakukan oleh akun @jogjafoodhunterofficial baik yang selaras dengan penelitian terdahulu maupun penemuan terbaru dari peneliti. Dari penelitian terdahulu ditemukan beberapa teknik digital marketing yaitu iklan, storytelling, komedi, diskon, testimoni, tagar, dan promo. Selain itu, peneliti menemukan beberapa temuan teknik digital marketing terbaru yang tidak ditemukan pada penelitian terdahulu. Penemuan tersebut adalah audio musik, cashback dan feedback. Saran untuk penelitian selanjutnya, diharapkan dapat memaksimalkan proses pengumpulan data, tidak hanya dengan menggunakan analisis konten akan tetapi, data diperoleh dengan menggunakan observasi, wawancara dan membagikan kuisioner terhadap pembuat konten agar data yang didapat lebih menyeluruh. Diharapakan dengan adanya promosi dengan menggunakan teknik digital marketing, dapat meningkatkan engagement yang berdampak pada pelaku usaha kuliner.

\section{Referensi}

Abdulhakim, A. (2019). Memahami Pengalaman Komunikasi Orang TuaAnak Ketika Menyaksikan Tayangan Anak-anak di Media Sosial Tik Tok (Doctoral dissertation, Faculty of Social and Political Science).
Akbar, A. (2006). Cepat dan Mudah Membuat Situs Internet.

Bulele, Y. N. (2020, November). Analisis Fenomena Sosial Media dan Kaum Milenial: Studi Kasus Tiktok. In Conference on Business, Social Sciences and Innovation Technology (Vol. 1, No. 1, pp. 565-572).

Coviello, N., Milley, R., \& Marcolin, B. (2001). Understanding IT-enabled interactivity in contemporary marketing. Journal of interactive marketing, 15(4), 18-33.

Chaffey, D. (2015). Digital Business and ECommerce Management, Strategy, Implementation, and Practice. Pearson Education Limited.

Dewa, C. B., \& Safitri, L. A. (2021). Pemanfaatan Media Sosial Tiktok Sebagai Media Promosi Industri Kuliner Di Yogyakarta Pada Masa Pandemi Covid-19 (Studi Kasus Akun TikTok Javafoodie). Khasanah Ilmu-Jurnal Pariwisata Dan Budaya, 12(1), 65-71.

Ha, Y. W., Park, M. C., \& Lee, E. (2014). A framework for mobile SNS advertising effectiveness: user perceptions and behaviour perspective. Behaviour \& Information Technology, 33(12), 13331346.

Hayu, R. S. (2019). Smart Digital Content Marketing, Strategi Membidik Konsumen Millennial Indonesia. (JMK) Jurnal Manajemen dan Kewirausahaan, 4(1), 61-69.

Indrawati, K. A. P., Sudiarta, I N., \& Suardana, I W. (2017). Efektivitas Iklan Melalui Media Sosial Facebook dan Instagram Sebagai Salah Satu Strategi Pemasaran di Krisna Oleh-Oleh Khas Bali. Jurnal Analisis Pariwisata, 17(2), 78-83.

Kirk, J., Miller, M. L., \& Miller, M. L. (1986). Reliability and validity in qualitative research (Vol. 1). Sage.

Kotler, P., \& Amstrong, G. (2004). DasarDasar Pemasaran Jilid 2. Alih Bahasa, Alexander Sindoro. Jakarta Prenhallindo.

Kotler, P., \& Keller, K. L. (2012). Marketing Management. 14EEdition. NewJersey: Prentice Hall.

Leskin, P. (2020). TikTok Surpasses 2 Billion Downloads and Sets A Record For App Installs in A Single Quarter. Business Insider. 
Lexy, J. M. (2010). Qualitative research methodology. Bandung: Remaja Rosdakarya.

Oktavia, Y. (2019). Pengaruh Hashtag Engagement \#Peoplewearoemahetnik Di Media Sosial Instagram Terhadap Brand Image Ukm Oemah Etnik (Doctoral Dissertation, Universitas Airlangga).

Puspitarini, D. S., \& Nuraeni, R. (2019). Pemanfaatan Media Sosial Sebagai Media Promosi. Jurnal Common, 3(1), 71-80.

Rasyid, M. H. (2020). Pembelajaran Puisi Secara Daring Dengan Media Pembelajaran Berbasis Aplikasi (Tik Tok) Kelas X Sma Negeri 3 Pati. In Prosiding Seminar Nasional Pascasarjana (PRO SNAMPAS) (Vol. 3, No. 1, pp. 352-358)

Romo, Z. F. G., Medina, I. G., \& Romero, N. P. (2017). Storytelling and social networking as tools for digital and mobile marketing of luxury fashion brands. Int. J. Interact. Mob. Technol., 11(6), 136-149.

Saladin, D., \& Oesman, Y. (2002). Intisari Pemasaran dan Unsur Pemasaran. Bandung: Lindakarya.

Saveria, R. A. (2016). Analisis Digital Marketing Dalam Strategi Integrated Marketing Communication Kampanye Politik (Studi Kasus Komunitas Teman Ahok).

Sawicki, A. (2016). Digital Marketing. Journal World Scientific News, 48, 82-88.

Setyaningrum, N., Waluyo, H. D., \& Wijayanto, A. (2014). Pengaruh Kualitas Produk, Citra Merek dan Promosi Penjualan dalam Pengambilan Keputusan Pembelian Produk Mie Sedaap. Jurnal IImu Administrasi Bisnis, 3(1), 197-204.

Stathopoulou, A., Borel, L., Christodoulides, G., \& West, D. (2017). Consumer Branded \#hashtag Engagement: Can Creativity in TV Advertising Influence Hashtag Engagement?. Psychology \& Marketing, 34(4), 448-462.

Su, Y., Baker, B. J., Doyle, J. P., \& Yan, M. (2020). Fan engagement in 15 seconds: Athletes' relationship marketing during a pandemic via TikTok. International Journal of Sport Communication, 13(3), 436-446.
Tabroni, T., \& Komarudin, M. (2021). Strategi Promosi Produk Melalui Digital Marketing Bagi Umkm Terdampak Pandemi Covid'19 Berdasarkan Keputusan Konsumen. Jurnal Riset Entrepreneurship, 4(1), 49-57.

Tjiptono, F. (2008). Strategi Pemasaran Edisi 3. Yogyakarta: Andi.

Weiss, G. (2020, April 28). TikTok added 12 million unique U.S. visitors in March, as watch-time surges in quarantine. Tubefilter. Diakses dari https://www.tubefilter. com/2020/04/28/tiktok-added-12million-unique-us-visitors-in-march/

Zuchdi, D. (1993). Seri Metodologi Penelitian, Panduan Penelitian Analisis Konten. 